\title{
The Concept of Criminal Law for Personnel of Narcotics Abuse
}

\author{
Dhian Artwitadibrata ${ }^{*}$ and Akhmad Khisni ${ }^{* *}$ \\ *) Student of Master of Law, Faculty of Law, Universitas Islam Sultan Agung \\ Semarang, E-mail: peckoh76@gmail.com \\ ${ }^{* *}$ Faculty of Law Universitas Islam Sultan Agung
}

\begin{abstract}
The purpose of this paper is to review and analyze the juridical review by the prosecutor in criminal procedural law. In this paper the writer uses the normative juridical method. In the conclusion of the discussion that in handling narcotics cases, especially offenders who are more emphasized as victims or addicts, judges in Indonesia can be said to rarely make legal breakthroughs that emphasize social values and humanity that live in society. Judges in Indonesia only see the criminal side in the Act regardless of the negative effects of the decision, the result is that imprisonment is only seen as providing a deterrent effect to the perpetrator of a criminal act. According to the Narcotics Law, victims of narcotics users are sentenced to imprisonment because drug users are classified as criminal offenders. This contradicts the legal theory of victimology. Several countries have proven that decriminalization policies have an effect on reducing narcotics abuse. The optimum model of punishment for victims of narcotics users is a process outside the legal process, in which all victims of narcotics users report themselves to be rehabilitated. Meanwhile, for those who did not report themselves, the police and / or BNN made arrests and were immediately escorted and handed over to the rehabilitation.
\end{abstract}

Keywords: Criminal Law; Perpetrators; Narcotics Abuse.

\section{Introduction}

The Indonesian nation is actively carrying out development. The rapid growth and progress of the development of people's lives as a result and process of the implementation of development in all fields of social, political, economic, security and cultural life has also brought negative impacts in the form of increasing the quality and quantity of various kinds of crimes which are very detrimental and unsettling to society. According to I Made Darma Weda, the increase in various kinds of crimes is a reality of the times that cannot be avoided, and crime is a problem that humans experience from time to time. ${ }^{1}$ Therefore, where there are humans there is a potential for crime to occur.

Judges, prosecutors, police and lawyers are those who are directly or indirectly involved in the law enforcement process. The law enforcement harmonizes values, rules and behavior, for example the values of legal certainty with legal equivalence, law enforcement ranges from taking action and maintaining peace with the aim of justice. $^{2}$

Recently narcotics and illegal drug crimes have been transnational in nature carried out with a high modus operandi and sophisticated technology, law enforcement officials are expected to be able to prevent and overcome these crimes in order to

\footnotetext{
${ }^{1}$ Weda, I Made Darma. (1999). Kriminologi. Jakarta: PT. Raja Grafindo Persada. p. 11.

${ }^{2}$ Soekanto, Soerjono. (1993). Sendi-Sendi Ilmu Hukum. Bandung: PT. Cipta Aditya Bhakti. p. 35
} 
improve morality and the quality of human resources in Indonesia, especially for generations nation's next generation. ${ }^{3}$ The world is increasingly not conducive to social problems due to illegal drug use. Globally, the United Nation on Drugs and Crime (UNODC) estimates that between 155 and 250 million people or 3.5-5.7 percent of the world's population aged 15-64 years use an illegal substance at least once a year. ${ }^{4}$

The problem of drug abuse in Indonesia has not decreased, but has become increasingly complex. The increase was evidenced by the increase in the number of users and dealers who were caught ${ }^{5}$, as well as the disclosure of a drug factory syndicate by BNN that was apparently built in Indonesia. Several incidents caused by drug abuse also make people feel concerned, such as the accident by Afriyani which resulted in nine people dying, the arrest of the pilot consuming shabu-shabu, and police officers who are known to be drug users. These are some examples of cases that have troubled the community. ${ }^{6}$

In line with the increasing abuse of narcotics, the government has made efforts to crack down on syndicates and dealers by providing severe penalties, even up to the death penalty. As for victims of users or addicts, the government has made efforts to reduce the adverse effects of narcotics use, namely by providing rehabilitation facilities, both medically and socially. ${ }^{7}$ This is done so that victims of narcotics users can recover again, become productive humans, be able to work to meet the needs of life and their families, and become a healthy and strong generation of the nation.

In an effort to combat the dangers of narcotics, currently it is estimated at 5.1 million people. The Indonesian government has made policy breakthroughs or what is called a criminal policy on various occasions, namely issuing a special law on narcotics. Currently, the law applied is Act No.35 of 2009 concerning narcotics, as a revision of Act No.5 and Act No.22 of 1997 concerning narcotics and psychotropic substances. In the application of Act No.35 of 2009 concerning narcotics, drug users classified as addicts will receive prison sanctions as in the criminal justice system. But the term addressed to this group of addicts is categorized as a group of victims of self-abuse (self-victimization). ${ }^{8}$

However, the policy to place victims of narcotics users in rehabilitation places cannot work properly because it is still collided with the provisions of the Narcotics Law, which in this case victims of narcotics users are still positioned as perpetrators of criminal

\footnotetext{
${ }^{3}$ Suhada and Aryani Witasari, Legal Analysis Of Giving Remission To Fostered Citizens Of Criminal Acts In Narcotics In The Narcotics Special Class Ila Gintung Cirebon, Jurnal Internasional Daulat Hukum, Vol.3 No.1, March 2020, url: http://jurnal.unissula.ac.id/index.php/RH/article/view/8428/3934

4 Simanungkalit, Parasian. (2011). Globalisasi Peredaran Narkotika dan Penanggulangannya di Indonesia. Jakarta: Yayasan Wajar Hidup. p. 86

${ }^{5}$ Oscar Stefanus Setjo and Umar Ma'ruf, Investigation of Children Which Conflicting With Law in Narcotics Criminal Acts In Law Area of the Semarang City Police Jurisdiction, Jurnal Internasional Daulat Hukum, Vol.3 No.2, June 2020, url: http://jurnal.unissula.ac.id/index.php/RH/article/view/9851/4156

${ }^{6}$ Simanungkalit, Parasian. (2012). Model Pemidanaan yang Ideal Bagi Korban Pengguna Narkoba di Indonesia, Jurnal Yustisia, Vol.1 No.3, September-December. p. 80

7 lin Khaeriyatun Ni'mah and Sukarmi, Analysis On Drug Crime Distribution (G List) Kind Of Narcotics (Case Study In Court Decision In Region III Cirebon), Jurnal Internasional Daulat Hukum, Vol.2 No.4, December 2019, url: http://jurnal.unissula.ac.id/index.php/RH/article/view/8436/3912

8 Siagian, Amrizal. (2015). Penegakan Hukum Pidana Terhadap Korban Pecandu Narkoba di Indonesia, Jurnal Sosial dan Budaya Syari, UIN Syarif Hidayatullah, Vol.2 No.2.
} 
acts, as a result they do not receive maximum treatment and recovery because have to languish in prison. If observed carefully, especially from a medical perspective, many experts argue that in fact individual drug users are victims of syndicates or illicit drug trafficking and syndicates that find it difficult to escape from dependence. Even though these users may actually want to escape from the bondage of the drugs that surround them, but because the nerves have been poisoned by opium by addictive substances it is difficult to do. Therefore, users or addicts require different treatment from patients in general.

According to a juridical perspective, drug users cannot be categorized as criminals because the nature of a crime must cause a victim and the victim is someone else (an act must take place that involves harm inflicted on someone by the actor). This view leads to the understanding that drug users are a form of crime without victim. This means that if you are the only victim yourself, then it cannot be said to be a crime, so it cannot be punished.

In the context of the conviction of victims of drug abuse, problems arise when the criminal threat formulated by the government together with the House of Representatives (DPR-RI) and has been ratified into Law Number 5 of 1997 concerning Psychotropics (hereinafter referred to as the Psychotropic Law) and Law Number 22 of 1997 on Narcotics which was later changed to Law Number 35 of 2009 concerning Narcotics (hereinafter referred to as the Narcotics Law), there are still contradictions, confusion, discrepancies, and also diversity in applying these legal products, especially in determining the sanctions. On the one hand, drug users are sentenced to prison, on the other hand, they are rehabilitated. Although the Law clearly states that victims of drug users are entitled to undergo treatment and / or treatment through rehabilitation, however, in reality, judges rarely choose to impose rehabilitation sentences. Based on the facts, even though it is obligatory to rehabilitate, the punishment applied to victims of drug users is still in the form of imprisonment.Based on the above background, the writer needs to analyze with the research objectives, namely to analyze the optimal criminal law concept for narcotics users in Indonesia as guidelines for law enforcement officers in handling drug abuse crime.

\section{Research method}

To conduct a study in this paper the author uses the normative juridical method, which is a type of approach using statutory provisions in force in a country or a doctrinal legal approach method, namely legal theories and opinions of legal scientists, especially those related to the issues discussed. ${ }^{9}$ The problem approach will then be sharpened with a conceptual approach (Conceptual Approach), which is an approach that is carried out using concepts that are understood from the thoughts of experts or experts in the fields related to the issues discussed.

\section{Result and Discussion}

\subsection{The optimal concept of criminal law Narcotics Users in Indonesia}

\footnotetext{
${ }^{9}$ Soemitro. (1998). Metodologi Penelitian Hukum dan Jurimetri. Jakarta: Ghalia Indonesia. p. 24
} 
There are several stages and patterns of illegal drug use, leading to dependence or addiction, which are divided into five stages of development, namely 1 ) experimental use. At this stage, the influence of peer groups is very large, such as close friends or other people who offer to use drugs. 2) Social use patterns. The pattern of social use is the use of drugs for social purposes and the desire to be recognized by the group. 3 ) Situational use patterns. At this stage the user will usually try to consume actively. 4) Habituation pattern (abuse / abouse). At this stage the use will often be carried out and it is generally at this stage that the dependency process occurs. 5) The pattern of dependence (compulsive dependent use). ${ }^{10}$

Meanwhile, there are three reasons that motivate someone to use drugs: 1) anticipatory beliefs, namely the perpetrators who use drugs with the aim of gaining recognition in a certain status. 2) Relieving beliefs, namely the perpetrators who use drugs to eliminate feelings of disappointment, sadness, anger, despair, tension and other unpleasant feelings. 3) Permissive beliefs or facilitative beliefs, namely the actors who use drugs as actions which according to the values of the perpetrators are not acts that violate norms. ${ }^{11}$

Based on several opinions of legal experts regarding the typology of victims in the victimology perspective, it can be stated that a drug addict is a self-victimizing victim, that is, someone who becomes a victim because of his own actions. However, there are also those who classify it into victimless crime because these crimes usually do not target victims, all parties are involved..$^{12}$ In addition, drug addicts can also be categorized as a crime without victim. The definition of a victimless crime means that this crime does not cause victims at all but the perpetrator as the victim. Meanwhile, in the category of crime, an evil act must cause a victim and the victim is someone else (an act must take place that involves harm inflicted on someone by the actor). This means that if you are the only victim yourself, it cannot be said to be a crime.

A criminal act or act against the law is committed by someone to another person, if there is no other party who is the victim, then as decided by the Constitutional Court through Decision Number 1 / PUU-IX / 2011, it cannot be said to be a criminal act or delict because of its nature. General criminal act is an act against the law, namely an act that violates the norms in such a way as to injure the legal interests of others or endanger the interests of others. ${ }^{13}$ This Constitutional Court court decision was taken to strengthen the opinion of legal experts as well as to convince researchers that the victim because of his own actions was not a crime. Thus, a person who uses drugs for himself and the act does not cause harm and / or cause a victim, the user cannot be categorized as a criminal act. ${ }^{14}$

\footnotetext{
${ }^{10}$ Abadinsky, Howard. (2008). Drug Use and Abuse: A Comprehensive Introduction. USA: Wadsworth. p. 240

${ }^{11}$ T. Beck, Aaron. (1993). Cognitive Therapy of Substance Abuse. New York: The Guilford Press. p.35

12 Manshur, Dikdik M Arief dan Elisatris Gultom. (2007). Urgensi Perlindungan Korban Kejahatan. Jakarta: PT Raja Grafindo Persada. p. 49-51

${ }^{13}$ Asep Suherdin and Maryanto, Analysis of Law Enforcement to Drugs Criminal Act in Military Environment (Case Study in Jurisdiction of Military Court II/09 Bandung), Jurnal Internasional Daulat Hukum, Vol.2 No.4, December 2019, url: http://jurnal.unissula.ac.id/index.php/RH/article/view/8357/3872

${ }^{14}$ Simanungkalit, Parasian. (2012). Op.Cit, Vol.1 No.3, September-December. p. 83
} 
According to Moeljatno, as quoted by Tongat, it is stated that criminal law is part of the overall law applicable in a country, which establishes the bases or rules for: a. determine which actions should not be carried out, which are prohibited, accompanied by threats or sanctions in the form of certain crimes for those who violate the prohibition; b. determine when and in what cases the perpetrator who has violated these prohibitions can be imposed or sentenced to the punishment as imposed; c. determine in what way the punishment can be carried out if a person is suspected of having violated the prohibition. ${ }^{15}$

The nature of the crime as "ultimum remedium" requires that punishment is not used as a means if it is not absolutely necessary. Because the punishment is not only felt bad at the time it is served, but after that the person who is subjected to it still feels the consequences in the form of a "stamp" by the community that he had committed "evil". This stamp is called "stigma" in science. So the person gets stigmatized; and if it doesn't disappear, it will be as if he was sentenced to life. ${ }^{16}$

Basically, imprisonment of victims of drug users cannot change their actions as drug users because the perpetrator is an addicted person, suffering from pain that should receive treatment and care. However, because the act has been determined as an unlawful act, and has been stipulated in the Narcotics Law, the act is subject to criminal sanctions. This is in accordance with the legality principle stated in Article 1 paragraph (1) of the Criminal Code, namely that a person cannot be convicted except for an act formulated in an existing statutory regulation (nullum delictum nula poena sine praevia lege poenali).

Regulations for criminal sanctions against narcotics users for themselves are contained in Article 127 of the Narcotics Law. Using narcotics on one's own means that the use is carried out without the supervision of a doctor. The use of narcotics without the doctor's supervision is an act "without rights and against the law". This means that as long as the laws and regulations still include the threat of imprisonment for narcotics users, even though for himself, the punishment will always exist. On that basis, narcotics users or addicts can be criminalized. Even so, the Narcotics Law also regulates rehabilitation for users or addicts, namely Article 54, Article 55, Article 56, Article 57, Article 58 and Article 103. In Article 103 of the Narcotics Law,

First, the judge may decide to order the person concerned to undergo treatment and / or treatment if the narcotics addict is found guilty of committing a narcotics crime. Second, the judge may decide to order the person concerned to undergo treatment and / or treatment, if the narcotics addict is not proven guilty of committing a narcotics crime. In cases of drug abuse in Indonesia, victims of narcotics users who are caught using narcotics are immediately put into state detention centers (detention centers) or police cells. Then to develop an investigation, the victim is still in detention. When in the investigation process corroborating evidence has been collected, then the investigator will send the Investigation Procedure File (BAP) to the prosecutor's office to form a public prosecutor who then makes an indictment and submits it to the district court. During this process victims who use narcotics are transferred from the

\footnotetext{
${ }^{15}$ Tongat. (2008). Dasar-Dasar Hukum Pidana Indonesia dalam Perspektif Pembaharuan. Malang: UMM Press. p.14

${ }^{16}$ Soedarto. (2007). Hukum dan Hukum Pidana. Bandung: PT Alumni. p.24
} 
police detention center to the prosecutor's detention center, or detention center at a correctional facility (LP). The head of the court, who has received the indictment from the prosecutor's office, then forms a panel of judges to summon the accused. The case was then tried in a district court, and the victim who used narcotics who had been convicted immediately served his sentence in prison. ${ }^{17}$

The criminal model, as described above, by placing victims of narcotics users in custody (even though the provision is that they have the right to treatment / care) will actually make it difficult for victims of narcotics users to recover from dependence. Moreover, prison conditions that are not supportive will have a negative impact and will worsen the mental and health conditions suffered by narcotic users.

Imposing imprisonment to victims of narcotics users before the Narcotics Law is amended because there has been a legal breakthrough, the imposition of criminal sanctions on victims of narcotics users is not sentenced to imprisonment but in the ruling a judge can order to be placed in a rehabilitation place. As for the expected model of punishment, someone who is caught using narcotics for himself since being caught by the police or BNN is immediately put in a rehabilitation place. During the legal process, the judges remain in the rehabilitation area to undergo treatment and recover from drug dependence.

Before the Narcotics Law, related to the criminalization of narcotics users (Article 127 Paragraph 1 of the Narcotics Law), was amended through the submission of a Judicial Review to the Constitutional Court, or through the submission of amendments to the Law by the government to the legislative body (DPR-RI), the judge in deciding drug cases can make a legal breakthrough by including one of the dictums in the verdict to order the defendant to take medication and rehabilitation. This is as mandated in Article 54 and Article 103 of the Narcotics Law and also based on SEMA Number 4 of 2010 and Government Regulation Number 25 of 2011. Victims of drug users who have been arrested by the police or authorized institutions (BNN) should not be placed in detention centers or a police cell, but immediately placed in a rehabilitation area. Meanwhile, at the time of the case investigation process, from the level of investigation to trial (criminal justice system), victims of drug users are still placed in rehabilitation centers. If in court it is proven that he is only a drug user himself, then the judge should give an acquittal on the condition that he is rehabilitated until he is completely cured. This applies as long as Article 127 of the Narcotics Law has not been amended or revoked. ${ }^{18}$

To apply the criminal model, as explained above, is actually not difficult. Because legal instruments are available through the Narcotics Law (Article 54, Article 103 and Article 127 paragraphs (2) and (3)) as well as the mandate of the Supreme Court through SEMA Number 4 of 2010 into the Medical and Social Rehabilitation Institution, which becomes the guide for court judges state and high court in deciding cases. In addition, there are still two government regulations that can be used as a basis for implementing the ideal model, namely Government Regulation Number 25 of 2011 and Regulation of the Head of BNN Number 2 of 2011.

\footnotetext{
${ }^{17}$ Simanungkalit, Parasian. (2012). Op.Cit, Vol.1 No.3, September-December p. 86

${ }^{18} \mathrm{Ibid}, \mathrm{p} .86$
} 


\section{Closing}

In handling narcotics cases, especially offenders who are more emphasized as victims or addicts, judges in Indonesia can be said to rarely make legal breakthroughs that emphasize social values and humanity that live in society. Judges in Indonesia only see the criminal side of the law without seeing the negative effects of the decision, as a result imprisonment is only seen as a deterrent effect for the perpetrator of a criminal act. According to the Narcotics Law, victims of narcotics users are sentenced to imprisonment because drug users are classified as criminal offenders. This contradicts the legal theory of victimology. Several countries have proven that decriminalization policies have an effect on reducing narcotics abuse. The optimum model of punishment for victims of narcotics users is a process outside the legal process, in which all victims of narcotics users report themselves to be rehabilitated. Meanwhile, for those who did not report themselves, the police and / or BNN made arrests and were immediately escorted and handed over to the rehabilitation site.

The government together with the DPR-RI as legislative instruments need to immediately change the Narcotics Law, especially articles that still position narcotics users as criminals, so that in the future narcotics users will no longer be criminals but as victims of the crime of narcotics trafficking. The Ministry of Health needs to prepare rehabilitation centers, both in the form of hospitals and community health centers that deal specifically with victims of drug users. In addition, the government needs to encourage all components of the nation to participate and establish rehabilitation places that can be used as a reference for drug users or addicts.

\section{References}

Journals:

[1] Siagian, Amrizal. (2015). Penegakan Hukum Pidana Terhadap Korban Pecandu Narkoba di Indonesia, Jurnal Sosial dan Budaya Syari, UIN Syarif Hidayatullah, Vol.2 No.2.

[2] Asep Suherdin and Maryanto, Analysis of Law Enforcement to Drugs Criminal Act in Military Environment (Case Study in Jurisdiction of Military Court II/09 Bandung), Jurnal Internasional Daulat Hukum, Vol.2 No.4, December 2019, url: http://jurnal.unissula.ac.id/index.php/RH/article/view/8357/3872

[3] lin Khaeriyatun Ni'mah and Sukarmi, Analysis On Drug Crime Distribution (G List) Kind Of Narcotics (Case Study In Court Decision In Region III Cirebon), Jurnal Internasional Daulat Hukum, Vol.2 No.4, December 2019, url: http://jurnal.unissula.ac.id/index.php/RH/article/view/8436/3912

[4] Suhada and Aryani Witasari, Legal Analysis Of Giving Remission To Fostered Citizens of Criminal Acts In Narcotics In The Narcotics Special Class Ila Gintung Cirebon, Jurnal Internasional Daulat Hukum, Vol.3 No.1, March 2020, url: http://jurnal.unissula.ac.id/index.php/RH/article/view/8428/3934

[5] Simanungkalit, Parasian. (2012). Model Pemidanaan yang Ideal Bagi Korban Pengguna Narkoba di Indonesia, Jurnal Yustisia, Vol.1 No.3, September-December.

[6] Oscar Stefanus Setjo and Umar Ma'ruf, Investigation of Children Which Conflicting With Law in Narcotics Criminal Acts In Law Area of the Semarang City Police Jurisdiction, 
Jurnal Internasional Daulat Hukum, Vol.3 No.2, June 2020, url: http://jurnal.unissula.ac.id/index.php/RH/article/view/9851/4156.

\section{Books:}

[1] Abadinsky, Howard. (2008). Drug Use and Abuse: A Comprehensive Introduction. USA: Wadsworth.

[2] Manshur, Dikdik M Arief dan Elisatris Gultom. (2007). Urgensi Perlindungan Korban Kejahatan. Jakarta: PT Raja Grafindo Persada.

[3] Simanungkalit, Parasian. (2011). Globalisasi Peredaran Narkotika dan Penanggulangannya di Indonesia. Jakarta: Yayasan Wajar Hidup.

[4] Soedarto. (2007). Hukum dan Hukum Pidana. Bandung: PT Alumni.

[5] Soekanto, Soerjono. (1993). Sendi-Sendi Ilmu Hukum. Bandung: PT. Cipta Aditya Bhakti.

[6] Soemitro. (1998). Metodologi Penelitian Hukum dan Jurimetri. Jakarta: Ghalia Indonesia.

[7] T. Beck, Aaron. (1993). Cognitive Therapy of Substance Abuse. New York: The Guilford Press.

[8] Tongat. (2008). Dasar-Dasar Hukum Pidana Indonesia dalam Perspektif Pembaharuan. Malang: UMM Press.

[9] Weda, I Made Darma. (1999). Kriminologi. Jakarta: PT. Raja Grafindo Persada. 